\title{
$\beta \mathrm{Ti}-\mathrm{Fe}$ 合金の等温時効挙動
}

\author{
井上 幸一郎*，池田 勝彦 ${ }^{* 2}$, 小松 伸也*2, 杉本 隆史*2, 亀井 清*3 \\ Isothermal Aging Behavior of $\beta$ Ti-Fe Alloys \\ Koichiro Inoue, Masahiko Ikeda, Shin-ya Komatsu, Takashi Sugimoto and Kiyoshi KameI
}

\begin{abstract}
Synopsis : The isothermal aging behavior of Ti- $-5,8$ and 10 mass $\% \mathrm{Fe}$ alloys at $673 \mathrm{~K}, 723 \mathrm{~K}$ and $773 \mathrm{~K}$ was investigated by resistivity and hardness measurements, X-ray diffractometry and transmission electron microscopy. The Time-Temperature-Transformation diagram of the alloys was determined. In $\mathrm{Ti}-5$ mass $\% \mathrm{Fe}$ and $\mathrm{Ti}-8$ mass $\% \mathrm{Fe}$, the isothermal $\omega$ phase precipitated by aging at all of the aging temperatures. Because the isothermal $\omega$ phase did not precipitate by $773 \mathrm{~K}$ aging in $\mathrm{T}-10 \mathrm{mass} \% \mathrm{Fe}$, the upper temperature limit for precipitation of isothermal $\omega$ phase in Ti-10mass $\% \mathrm{Fe}$ will situate between $723 \mathrm{~K}$ and $773 \mathrm{~K}$. Incubation period prior to nucleation of $\alpha$ phase is shortened with elevating aging temperature. The influence of Fe content on the time for nucleation of $\alpha$ phase was not clear. Only at $723 \mathrm{~K}$, resistivity and hardness of all specimens show second abrupt decrease by more than $600 \mathrm{ks}$ aging, which suggests the precipitation of TiFe.
\end{abstract}

Key words : titanium-iron alloy; metastable $\beta$ alloy; isothermal aging; resistivity; hardness; $\omega$ phase; $\alpha$ phase.

\section{1. 緒言}

$\beta$ 型チタン合金は高い比強度と優れた冷間加工性を示 し，航空宇宙産業を中心に用いられてきた ${ }^{1} 。$ 近年では自 動車部品 ${ }^{2}$ やゴルフクラブ ${ }^{3)}$ のような身近な製品にも適 用されている。しかし， $\mathrm{Ti}-15 \mathrm{~V}-3 \mathrm{Cr}-3 \mathrm{Sn}-3 \mathrm{Al}$ $\mathrm{Ti}-15 \mathrm{Mo}-5 \mathrm{Zr}-3 \mathrm{Al}$ を代表とする $\beta$ 型チタン合金にはバナジ ウム，モリテデンなどの高価な元素が多量に添加されてい るため，上述のような優れた特性にもかかわらず，素材コ ストが高く，用途拡大が進んでいない。このような状況か ら $\beta$ 型チタン合金の低コスト化が検討されている4)。

著者らは $\beta$ 安定化元素のなかで最も安価な鉄に注目し， $\mathrm{Ti}-\mathrm{Fe}$ 二元合金の焼入れ組織と比抵抗の関係を調査し，鉄 含有量が 4 mass \% (以後at. \%と表記しない限り \% は mass $\%$ を示す）以上で $\beta$ 相が残留することを確認した5)。また， $\beta \mathrm{Ti}-\mathrm{Fe}$ 二元合金の比抵抗, 硬さ, 組織の時効による変化を $373 \mathrm{~K}$ から $50 \mathrm{~K}$ 毎に $1173 \mathrm{~K}$ までの各温度で, 順次 $1.8 \mathrm{ks}$ 保持 する累積等時時効により調査した6)。その結果， $4 \sim 10 \% \mathrm{Fe}$ で時効 $\omega$ 相析出による硬化と $\alpha$ 相析出の開始にともなう時 効 $\omega$ 相の再固溶・消滅による軟化が認められた。 $4 \sim 6 \% \mathrm{Fe}$ 合金の過時効軟化状態では，焼入れ状態よ り硬さが大きく低下した。 Ti-V二元合金 ${ }^{7)}$ 累積等時時 効でも焼入れ状態よりもわずかに軟化することがある が, $\mathrm{Ti}-15 \mathrm{~V}-3 \mathrm{Cr}-3 \mathrm{Sn}-3 \mathrm{Al}^{8)}, \mathrm{Ti}-15 \mathrm{Mo}-5 \mathrm{Zr}^{9)}$, $\mathrm{Ti}-15 \mathrm{Mo}-5 \mathrm{Zr}-3 \mathrm{Al}^{(0)}$ などの合金には，このような過時効軟 化は見られず， $\beta \mathrm{Ti}-\mathrm{Fe}$ 合金の特徵の一つである。
$8,10 \% \mathrm{Fe}$ 合金では時効温度 $523 \mathrm{~K}$ まで， $\beta$ 相の濃度分離 または時効 $\omega$ 相の前駆段階 ${ }^{11)}$ と考えられる室温の比抵抗 増加と, 液体窒素温度の比抵抗を室温の比抵抗で除した抵 抗比の低下が認められた。

累積等時時効は少量の試料で多くの情報が得られるが, より詳細に時効挙動を検討するためには等温時効による調 查が必要である。本研究では前報 ${ }^{6)}$ に引続き, $\beta \mathrm{Ti}-\mathrm{Fe}$ 二元 合金の等温時効挙動を比抵抗と硬さ，X線回折による相同 定および透過型電子顕微鏡(TEM) 観察により調査した。

\section{2. 実験方法}

本研究に用いた試料は前報 ${ }^{(1)}$ と同一で, 鉄の含有量が5, $8,10 \%$ (以下各々 $\mathrm{T} 5 \mathrm{Fe}, \mathrm{T} 8 \mathrm{Fe}, \mathrm{T} 10 \mathrm{Fe}$ と記す) のもので ある。化学分析組成は $\mathrm{T} 5 \mathrm{Fe}$ が $5.10 \% \mathrm{Fe}-0.097 \% \mathrm{O}, \mathrm{T} 8 \mathrm{Fe}$ が $8.16 \% \mathrm{Fe}-0.137 \% \mathrm{O}, \mathrm{T} 10 \mathrm{Fe}$ が $9.98 \% \mathrm{Fe}-0.103 \% \mathrm{O}$ である。

約 $2 \times 2 \times 60 \mathrm{~mm}$ の比抵抗と硬さ測定用試験片，約 $2 \times 10 \times 10 \mathrm{~mm}$ の X線回折用試験片は石英ガラスのカプセル に $3 \mathrm{mPa}$ 以下に減圧封入し，1173Kに加熱した炉内に $3.6 \mathrm{ks}$ 保持して溶体化処理した。その後，カプセルをできるだけ 速く水水中に浸漬して破砕し, 急冷した。この状態を以下 STQ状態と表記する。

等温時効処理温度は, 前報 ${ }^{6}$ の累積等時時効の結果から 選んだ。前報の累積等時時効の結果, $673 \mathrm{~K}$ で時効 $\omega$ 相の 析出, $723 \mathrm{~K}$ ではそれらの一部再固溶と $\alpha$ 相の析出が起こ り, $773 \mathrm{~K}$ では時効 $\omega$ 相は消失し, $\alpha$ 相のみの析出が起こ 
つた。したがって，本試料の時効 $\omega$ 相と $\alpha$ 相の析出挙動を 検討する場合に $673 ， 723 ， 773 \mathrm{~K}$ が最適な時効温度である と判断してこれを採用した。

Fig. 1のように各等温時効温度の塩浴中で時効した後に 水水中に焼入れ，各種測定を実施した。その後，再び所定 の温度に加熱し，累積的に時効した。試料表面からの酸素 污染を防止するため，673Kでは $600 \mathrm{ks} ， 723 \mathrm{~K} て ゙ は 120 \mathrm{ks}$ ， $773 \mathrm{~K}$ では $60 \mathrm{ks}$ 時効後, 酸化膜を研磨除去した。その後は 溶体化処理と同様にカプセル封入して時効した後, 水水中 でカプセルを破砕して焼入れた。

室温と液体窒素温度で直流四端子法により電気比抵抗を 測定した。荷重 $4.9 \mathrm{~N}$ でのビッカース硬さを測定し，CuK $\alpha$ 線によるディフラクトメータ法でのX線回折を室温で実施 した。一部の試料についてはTEMで組織を観察した。 TEM観察用には, 厚さ約 $0.1 \mathrm{~mm}$ まで機械的に研磨した後, 液温約 $230 \mathrm{~K}$ の $6 \mathrm{Vol} \%$ 過塩素酸 $+35 \mathrm{Vol} \% \mathrm{n}$ ーブタノール $+59 \mathrm{Vol} \%$ メタノール液を用いて, ツインジェット法で電 解研磨した試料を用いた。

\section{3. 結果および考察}

\section{$3 \cdot 1$ 等温時効による比抵抗と硬さの変化}

Fig. 2 に各試料の $673 ， 723 ， 773 \mathrm{~K}$ での等温時効による液 体窒素温度での比抵抗 $\left(\rho_{L N}\right)$, 室温での比抵抗 $\left(\rho_{R T}\right)$, 抵抗

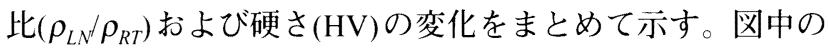
矢印は $0.06 \mathrm{ks}$ 以降で抵抗比の急减が認められる時効時間を 示している。

STQ状態では抵抗比が1より大きい見かけの負の温度依 存性が認められる。これは, 室温以下への冷却と加熱によ
る非熱的 $\omega$ 相の可逆的な生成消滅で説明されている $5.12-14) 。$ 等温時効による比抵抗, 抵抗比, 硬さの变化を以下にま とめる。

1) $\mathrm{T} 5 \mathrm{Fe}, \mathrm{T} 8 \mathrm{Fe}$ では最短の $0.06 \mathrm{ks}$ の時効で比抵抗，抵 抗比はSTQの值から大きく減少する。この減少は鉄含有 量が低く, 時効温度が高いほど顕著で，T10Feでは時効開 始直後の抵抗比と比抵抗の減少は小さい。

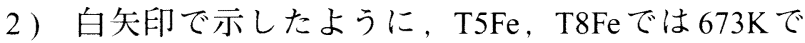
$300 \mathrm{ks}, 723 \mathrm{~K}$ で $6 \mathrm{ks}, 773 \mathrm{~K} て ゙ 0.3 \mathrm{ks}$ から，またT10Feでは $673 \mathrm{~K} て ゙ 300 \mathrm{ks}, 723 \mathrm{~K} て ゙ 6 \mathrm{ks}, 773 \mathrm{~K}$ で0.6 ks から比抵抗，抵 抗比の急減が認められる。この比抵抗, 抵抗比の急減は高 時効温度ほど短時間で現われる。

3 ）黑矢印で示したように，723K 時効ではすべての試 料で $600 \mathrm{ks}$ から再び比抵抗，抵抗比の急減が認められる。

4 ) T5Fe，T8Feは，すべての時効温度でSTQから $0.06 \mathrm{ks}$ にかけて大きく硬化する。T10Feは $673 \mathrm{~K} て ゙ は \mathrm{~T} 5 \mathrm{Fe}$ 等と同様に硬化するが，723K以上ではこの硬化は見られ ない。

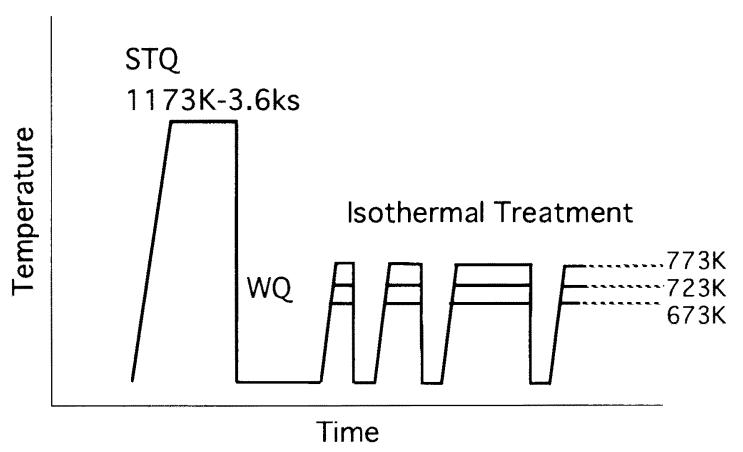

Fig. 1. Schematic diagram of solution treatment and accumulative isothermal aging.
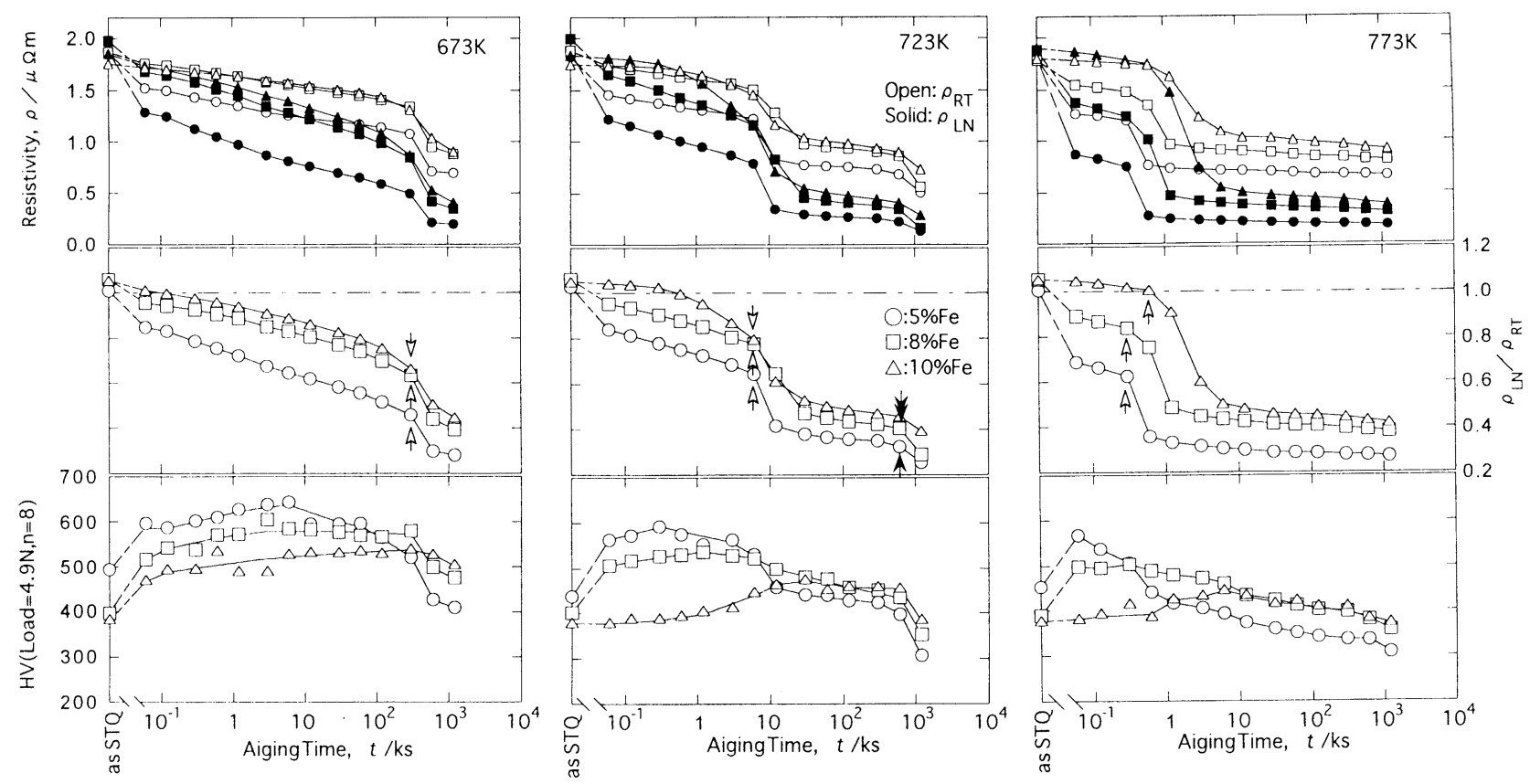

Fig. 2. Influence of Fe content and aging temperature on isothermal aging behavior. White arrows show first abrupt decrease in resistivity ratio, or start of $\alpha$ precipitation. Black arrows show second abrupt decrease suggesting TiFe precipitation. 

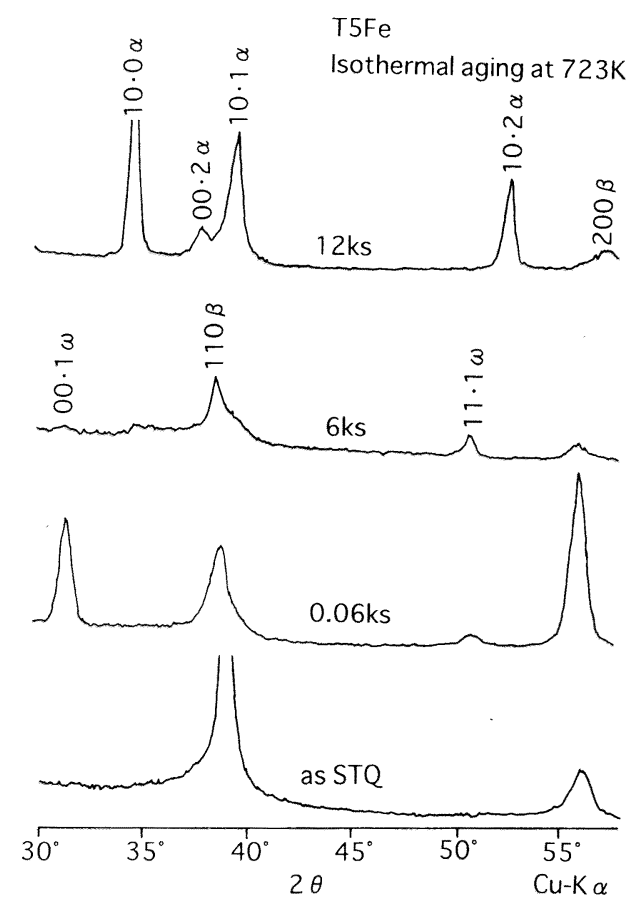

Fig. 3. Change in X-ray diffraction profile of $\mathrm{T} 5 \mathrm{Fe}$ with isothermal aging at $723 \mathrm{~K}$.

5 ) $\mathrm{T} 5 \mathrm{Fe}, \mathrm{T} 8 \mathrm{Fe}$ のすべての時効温度と $\mathrm{T} 10 \mathrm{Fe}$ の $673 \mathrm{~K}$ 時 効では白矢印の比抵抗，抵抗比急減開始時効時間から急激 な軟化が認められる。T10Feの723，773K 時効ではこの時 間以降で小さな硬化が始まる。

6) 723K 時効の黒矢印で示される $600 \mathrm{ks}$ から $1.2 \mathrm{Ms}$ に かけてすべての試料で軟化が見られる。

\section{$3 \cdot 2$ 比抵抗, 硬さ変化と組織の関係}

Fig. 2に示した等温時効挙動の鉄含有量と温度による変 化を説明するために, 時効後の相構成をX線回折で同定し た。また,一部の試料についてはTEM組織を観察した。

Fig. 3に723K 時効で変化した $55 \mathrm{Fe} の \mathrm{X}$ 線回折図形を示 す。STQ状態では $\beta$ 相の回折線のみが明暸に認められる。 STQ 状態では不明瞭だった $\omega$ 相の回折線は $0.06 \sim 6 \mathrm{ks}$ 時効 で明瞭になる。STQ状態で時に検出される $\omega$ 相の回折線 は非熱的 $\omega$ 相で，短時間の時効で急に明確になるものは 粒子内の鉄濃度減少をともなった不可逆的な時効 $\omega$ 相と 考えられる。

Fig. 2 で比抵抗と抵抗比が急減した $12 \mathrm{ks}$ 時効では $\omega$ 相の 回折強度は急落して, $\alpha$ 相の回折線が出現し, X線回折で 同定される相構成は $\alpha+\beta$ になる。

Fig. 3 と同様にすべての試料と時効温度について,X線 回折で同定した相構成の変化を Fig. 4にまとめて示す。図 中の実線は各温度でFig. 2の白矢印で示した抵抗比の急減 が始まる時間を結んだものである。また，黒矢印で示した $723 \mathrm{~K}-600 \mathrm{ks}$ からの急減は点線で記入した。一点鎖線は $\mathrm{T} 10 \mathrm{Fe}$ で時効 $\omega$ 相の回折線が検出される上限温度の推定値 である。

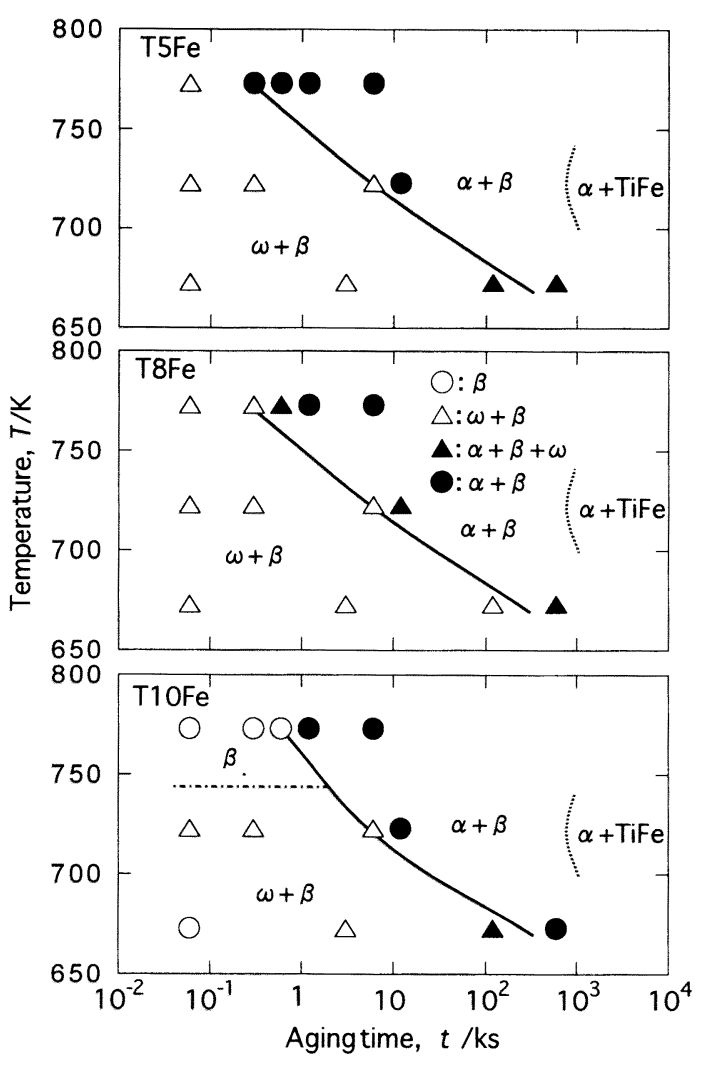

Fig. 4. Change in phase constitution by X-ray diffraction with isothermal aging. Limited Time-Temperature-Transformation diagrams, but extended about iron content.

$\mathrm{T} 5 \mathrm{Fe}$ ，T8Feの実線より短時間側では，同定された相構 成はほとんどが $\omega+\beta$ である。すでに報告したように $\mathrm{Ti}-5 \sim 15 \% \mathrm{Fe}$ 合金の STQ 状態では非熱的 $\omega$ 相が，ある程度 の体積率存在すると考えられるが，X線回折では明瞭な $\omega$ 相の回折線は検出されないら)とから $\mathrm{T} 5 \mathrm{Fe} ， \mathrm{~T} 8 \mathrm{Fe}$ の STQ から $0.06 \mathrm{ks}$ にかけての比抵抗と抵抗比の減少打よび硬化は 時効 $\omega$ 相の析出による。 $\mathrm{T} 5 \mathrm{Fe}$ の全時効温度と $\mathrm{T} 8 \mathrm{Fe}$ の $723 \mathrm{~K}$ 時効での硬さ変化は，実線までに極大を示した後にわずか に低下している。竹元ら ${ }^{15)}$ は Ti-14\%Mo 合金を $623 \mathrm{~K}$ で時 効し， $\omega$ 相のみが析出する場合にも1Ms以降で過時効軟化 を報告している。実線より短時間側で生じるわずかな軟化 は Ti-14\%Mo と同様な $\omega$ 相の過時効軟化によると考えられ る。

実線で示した時効時間付近から，X線回折で $\alpha$ 相の析出 が確認される。これらの時間とほぼ同時に始まる比抵抗， 抵抗比，硬さの急減は $\alpha$ 相の析出開始，すなわちそれまで の硬化を担ってきた時効 $\omega$ 相から $\alpha$ 相に析出相が順次変化 することによると考えられる。 $\beta \mathrm{Ti}-\mathrm{Fe}$ 合金の累積等時時効(1) でも時効 $\omega$ 相から $\alpha$ 相への析出相の変化にともなう軟化が 認められており，等温時効でもこの解釈は成立すると考え られる。

$\mathrm{T} 10 \mathrm{Fe}$ の $673 \mathrm{~K}-0.06 \mathrm{ks}$ 時効では明確な硬化が見られるの に $\omega$ 相の回折線が検出できなかった。しかし， $6 \mathrm{ks}$ まで時 


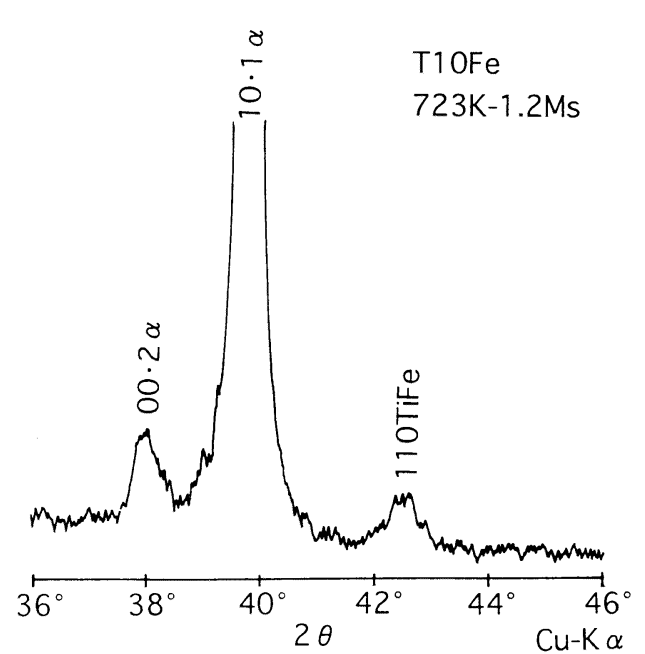

Fig. 5. X-ray diffraction profile of $\mathrm{T} 10 \mathrm{Fe}$ for resistivity measurement aged at $723 \mathrm{~K}$ for $1.2 \mathrm{Ms}$.

効すると $\omega$ 相の出現が確認されるので， 673K-0.06 ksでも 時効 $\omega$ 相が析出していたと推定される。T5Fe，T8Feより 鉄含有量が多く, $\beta$ 相の安定度が高い $\mathrm{T} 10 \mathrm{Fe}$ では時効 $\omega$ 相 の析出量が少なく, $0.06 \mathrm{ks}$ という短時間時効では $\omega$ 相の体 積率が小さくて回折線強度が低く, 検出できなかったため と推定される。

$\mathrm{T} 10 \mathrm{Fe}$ の $723 \mathrm{~K}$ 時効でも時効開始直後の $0.06 \mathrm{ks}$ 時効で $\omega$ 相の回折線が出現することは $\mathrm{T} 5 \mathrm{Fe}, \mathrm{T} 8 \mathrm{Fe}$ と同様であった が, 硬さは $0.3 \mathrm{ks}$ から $6 \mathrm{ks}$ にかけて緩やかに増加し, 他の 試料で見られる $\omega$ 相析出による硬化とは様子が異なる。 $\mathrm{T} 10 \mathrm{Fe}$ では $\beta$ 安定化元素である鉄含有量が多いことと時効 温度の上昇が $\omega$ 相析出の駆動力を低下させ， $723 \mathrm{~K} て ゙ は$ は時 効 $\omega$ 相の析出量が低下したと推測される。

T10Feも 673，723K 時効では, STQから実線までの領域 は $\omega$ 相の析出により比抵抗, 抵抗比および硬さが変化し たと考えられる。また，実線以降ではX線回折により $\alpha$ 相 が確認され， $\alpha$ 相析出により Fig. 2 の比抵抗, 抵抗比, 硬 さ変化は説明できる。

$\mathrm{T} 10 \mathrm{Fe}$ の 773K 時効では STQから実線までの時効時間で $\omega$ 相の回折線は認められなかった。また, 比抵抗, 抵抗比 および硬さの変化も非常に小さく, 時効 $\omega$ 相は析出して いないか，仮に析出していても非常に少量であると考えら れる。

$\beta \mathrm{Ti}$ 合金では一般に, $\beta$ 安定化元素の母相中濃度が増加 すると時効 $\omega$ 相の析出上限温度は低下する ${ }^{16)}$ 。T $10 \mathrm{Fe}$ では 等温時効での $\omega$ 相析出の上限温度が $723 \sim 773 \mathrm{~K}$ の間にあ り，773K 時効では $\beta$ 相から直接 $\alpha$ 相が析出している可能 性がある。

$723 \mathrm{~K}-1.2 \mathrm{Ms}$ 時効後の $\mathrm{T} 5 \mathrm{Fe}, \mathrm{T} 8 \mathrm{Fe}$ および $\mathrm{T} 10 \mathrm{Fe}$ の比抵抗 測定用試料でX線回折を実施した。一例として T10Feの結 果を Fig. 5 に示す。TiFeからの明確な規則反射は確認でき ないが，110TiFeからの反射と考えられる明確な回折線が 認められた。また，同様な回折図形が T5Fe，T8Feでも確

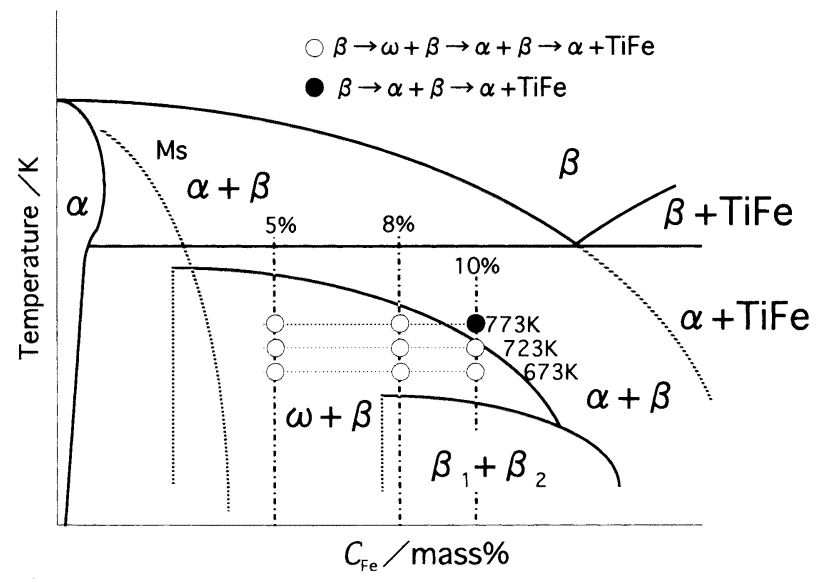

Fig. 6. Schematic representation of metastable phase diagram in Ti-Fe system.

認された。Franti ら ${ }^{17)}$ は $1273 \mathrm{~K}$ で溶体化処理したTi-5.2\% Fe および $\mathrm{Ti}-15 \% \mathrm{Fe}$ の部分的な $\mathrm{T}-\mathrm{T}-\mathrm{T}$ 曲線を組織観察で作成 し，723Kでは $\mathrm{Ti}-5.2 \% \mathrm{Fe}$ で $500 \mathrm{ks}, \mathrm{Ti}-15 \% \mathrm{Fe}$ で $1 \mathrm{Ms}$ 付近 から共析変態が始まるとしている。以上のことから $723 \mathrm{~K}-600 \mathrm{ks}$ から現われる比抵抗, 抵抗比の急減も TiFeの 析出によると考えられ, 比抵抗, 抵抗比の変化は相構成変 化によく対応している。

前報 ${ }^{6}$ の累積等時時効は少ない試料で比較的多くの情報 が得られ，時効 $\omega$ 相， $\alpha$ 相の析出温度範囲の見当をつける には勃果的な方法である。しかし各相の析出開始時間に関 しての情報を得ることができず，例えば723K 時効後の值 は673Kまでの時効の影響を受けている。本研究の等温時 効によって Ti-5，8，10\% Fe 合金の $673 ， 723 ， 773 \mathrm{~K}$ での時 効 $\omega$ 相と $\alpha$ 相の析出開始時間が明確になり，Fig. 4 は $\beta \mathrm{Ti}-\mathrm{Fe}$ 合金の局部的な $\mathrm{T}-\mathrm{T}-\mathrm{T}$ (Time-Temperature-Transformation)図とみなすことができる。これは，工業的にも重 要なデータであろう。

各相の生成領域と時効温度の関係を模式的に Fig. 6 に示 す。T5Fe, T8Feでは773Kまで, 全時効温度が $\omega+\beta$ 領域 内にあり, 時効による相変化は $\beta \rightarrow \omega+\beta \rightarrow \alpha+\beta \rightarrow \alpha+\mathrm{TiFe}$

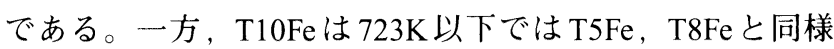

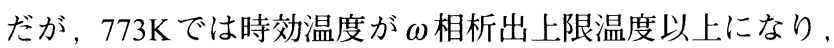
時効による相変化は $\beta \rightarrow \alpha+\beta \rightarrow \alpha+\mathrm{TiFe}$ になる。

累積等時時効では $\mathrm{T} 8 \mathrm{Fe}, \mathrm{T} 10 \mathrm{Fe}$ で $523 \mathrm{~K}$ まで $\beta$ 相の濃度 分離または時効 $\omega$ 相析出の前駆段階によると考えられる $\rho_{\mathrm{RT}}$ の増加と抵抗比の減少が認められている ${ }^{6)}$ 。本実験の 時効温度範囲内では確認されていないが, T8Fe, T10Feで は $673 \mathrm{~K}$ 以下に $\beta$ 相の濃度分離領域 $\left(\beta_{1}+\beta_{2}\right)$ が存在し, 相変 化は $\beta \rightarrow \beta_{1}+\beta_{2} \rightarrow \omega+\beta \rightarrow \alpha+\beta \rightarrow \alpha+\mathrm{TiFe}$ になと予想され る。

$\alpha$ 相の析出開始時間は $673,723 \mathrm{~K} て ゙ は$ 鉄含有量の明確な 影響は見られないが， $773 \mathrm{~K}$ 時効では $\beta$ 相の安定度が高い， 高鉄含有量の試料で遅くなる。

Fig. 4の 723K 時効で実線より短時間側の $0.3 \mathrm{ks}$ 時効した 


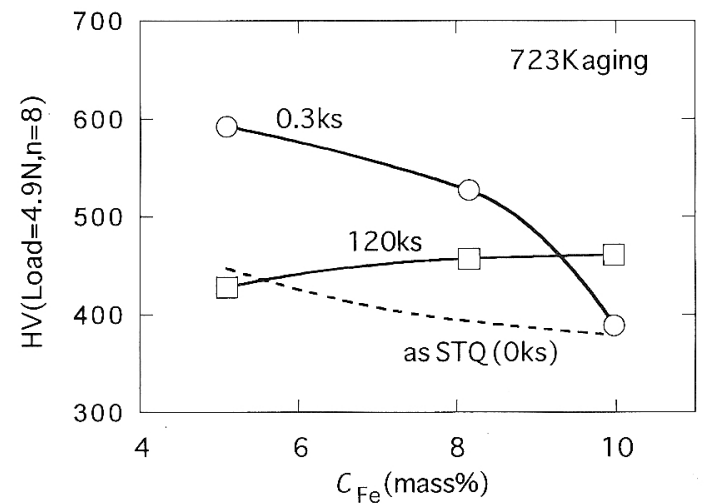

Fig. 7. Relationship between Fe content and hardness change by $723 \mathrm{~K}$ aging.

場合と，実線より長時間側で $\omega$ 相から $\alpha$ 相への変化が完了 した $120 \mathrm{ks}$ 時効の場合の硬さに及ぼす鉄含有量の影響を Fig. 7に示す。0.3ksでは，鉄含有量が低いほど硬さは高く， 鉄含有量の低いT5Fe，T8FeではSTQ状態から $150 \mathrm{HV}$ 程度 硬化する。一方，鉄含有量の高いT10Feではわずかに約 $10 \mathrm{HV}$ の硬化が見られる程度である。こ扎は鉄含有量の低 い試料ほど時効 $\omega$ 相の析出量が多いためと推定される。

$\alpha$ 相による析出硬化の極大に近い $120 \mathrm{ks}$ では，0.3 ksの場 合とは逆に鉄含有量が高いほど硬さは高く，T10FeでSTQ 状態より $80 \mathrm{HV}$ 程度硬化している。T5Feの723K-120 ks 時 効は，累積等時時効(6)でも見られた過時効軟化で，STQ状 態よりも硬さが低下する。このような過時効軟化は時効温 度の高い773Kではさらに顕著になる。

$723 \mathrm{~K} て ゙ 0.3 \mathrm{ks}$ 時効したときの T5Feと T $10 \mathrm{Fe}$ の TEM組織 をそれ乤れ Fig. 8 と Fig. 9 に示す。T5Fe，T10Feのどちらも 10 20 nmの析出物が観察される。この析出物は電子線回

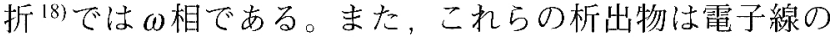
入射角变えて観察すると試料全面に析出していた。試料 膜厚は測定しておらず，Fig. 8，90暗視野像は一つのバリ アントのみなので，直接的な $\omega$ 相体積率の比較はできな いが，T5Feでは T10Feに比べて $\omega$ 相からの回折電子線強度 が強く, $\mathrm{T} 5 \mathrm{Fe} の \omega$ 相析出量が $\mathrm{T} 10 \mathrm{Fe}$ より多いと推定される。 この観察は，先の Fig. 7 で述べた鉄含有量の増加により時 効 $($ 相の析出量が減少するという説明を支持している。

$723 \mathrm{~K}-120 \mathrm{ks}$ 時効の T5Fe，T10Feの TEM組織を Fig.10と Fig.11に示す。T5Fe と T10 Feのどちらの試料でも，長径 $0.1 \sim 0.3 \mu \mathrm{m}$ の粗大な長楕円形に析出した多量の $\alpha$ 相が観察 される。両試料の $\alpha$ 相の析出状態には顕著な相違は認唯 れず，どちらも Orowan型の析出強化機構しか適用できな い過時効状態であると推測される。

STQでの硬さと過時效状態の硬さにおよぼす鉄含有量の 影響をFig.12に模式的に示す。STQ状態では $\beta$ 相本来の硬 さ注図中のAのように鉄の固溶硬化作用により鉄含有量と ともに緩やかに増加する。しかし， $\beta$ 相中に生成する非熱 的 $\omega$ 相がBのように硬さに寄与し，実際に測定される硬さ
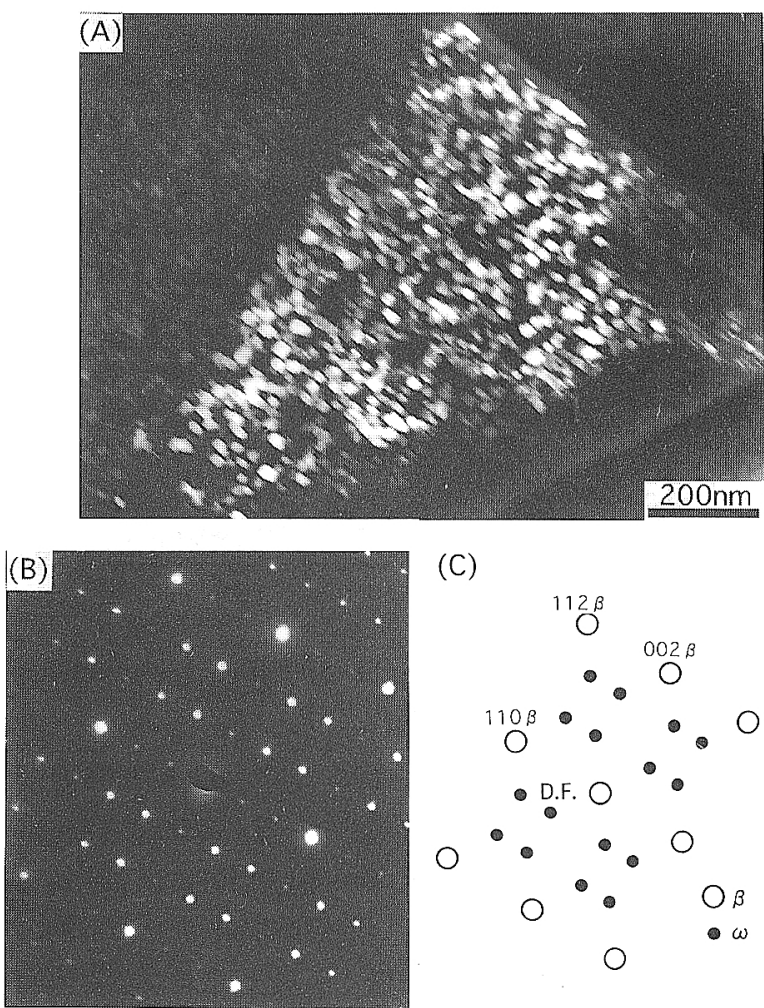

(C)

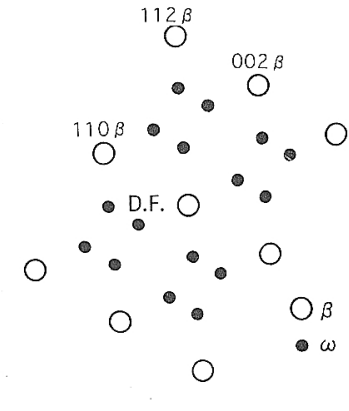

Fig. 8. TEM micrographs of T5Fe aged at $723 \mathrm{~K}$ for $0.3 \mathrm{ks}$ A) Dark field image, B) SAD pattern, beam direction is [110] $\beta$ and C) Key diagram of SAD pattern in B).
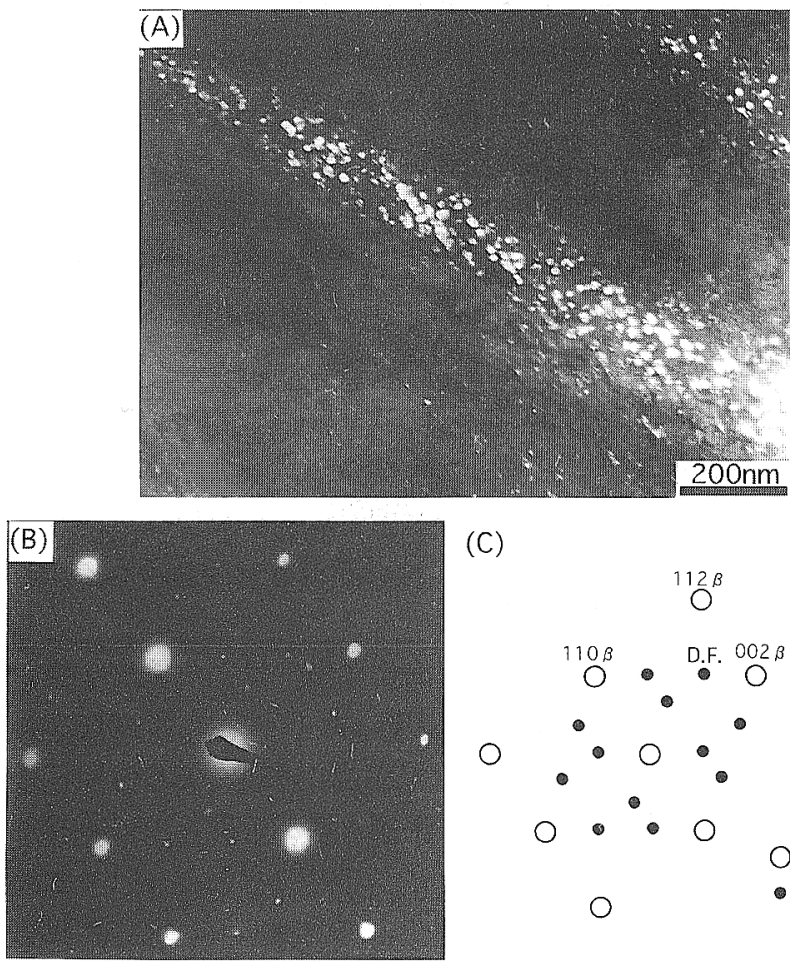

(C)

Fig. 9. TEM micrographs of $\mathrm{T} 10 \mathrm{Fe}$ aged at $723 \mathrm{~K}$ for $0.3 \mathrm{ks}$. A) Dark field image, B) SAD pattern, beam direction is [110] $\beta$ and $C$ ) Key diagram of SAD pattern in $B$ ). 
は $\beta$ 相本来の硬さと非熱的 $\omega$ 相による硬化の和 $\mathrm{A}+\mathrm{B}$ で表 わされる。このため非熱的 $\omega$ 相が室温でも多量に存在す る $10 \% \mathrm{Fe}$ 以下では鉄含有量が低い試料ほど硬さは高い5)

過時効状態では抵抗比が 1 以下になり，非熱的 $\omega$ 相は既 に消滅している。時効による硬さ変化は $\beta$ 相中の溶質原子 の濃縮と $\alpha$ 相の析出により生じる。 $\beta$ 相中の鉄濃度は， Fig. 6の状態図の $\beta$ 変態温度曲線を時効温度まで延長した 組成まで濃縮して，鉄含有量によらずほぼ一定となり，固 溶体硬化量もCで示されるようにSTQ状態よりはるかに 高いが，合金組成とは無関係にほぼ一定になる。

析出 $\alpha$ 相はFigs.10〜11に示したようにFigs. 8〜9に示し
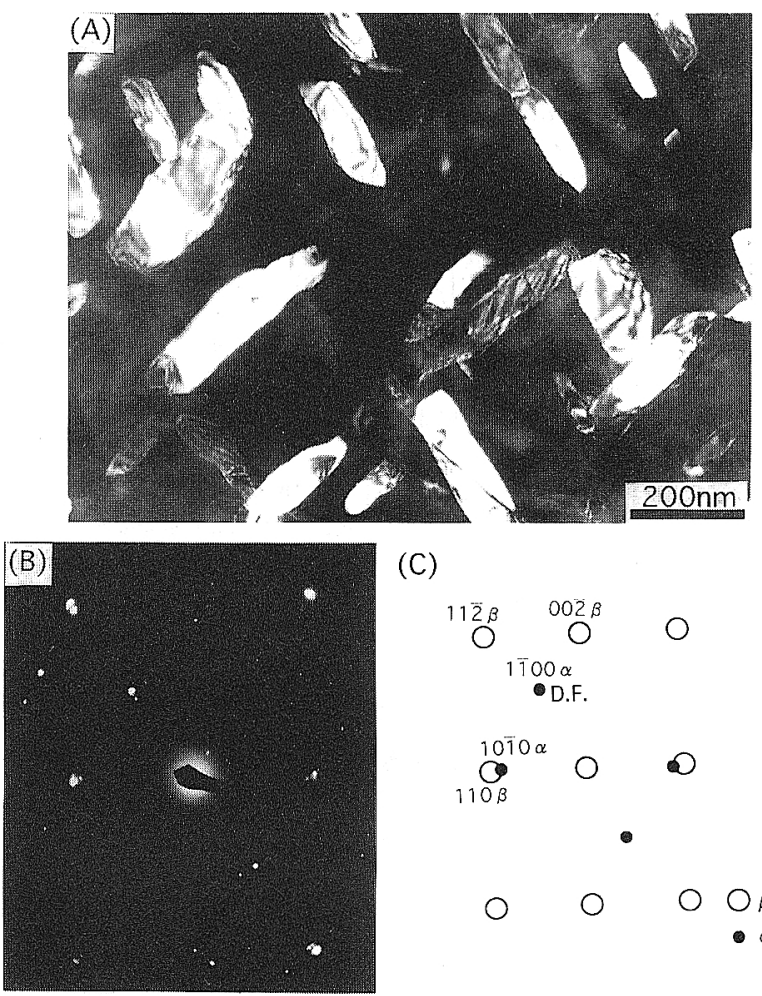

(C)

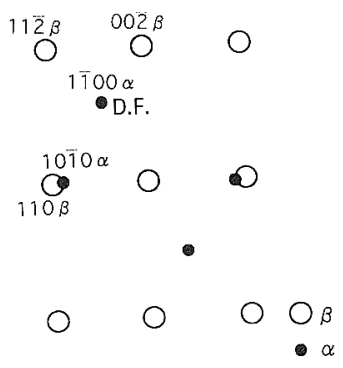

Fig. 10. TEM micrographs of $\mathrm{T} 5 \mathrm{Fe}$ aged at $723 \mathrm{~K}$ for $120 \mathrm{ks}$. A) Dark field image, B) SAD pattern, beam direction is [110] $\beta$ and $C$ ) Key diagram of $\mathrm{SAD}$ pattern in $\mathrm{B})$.
た時効 $\omega$ 相に比べてはるかに粗大化しており，分散状態 からくる析出硬化量は時効 $\omega$ 相に比べて非常に小さいと 考えられる。また，析出 $\alpha$ 相の大きさや析出形態に鉄含有 量の顕著な影響は認められなかった。しかしながら $723 \mathrm{~K}-120 \mathrm{ks}$ での $\rho_{L N}$ は全試料で $0.27 \sim 0.48 \mu \Omega \mathrm{m}$ 範囲にあ り，その值は鉄含有量の低い試料ほど低い。これは比抵抗 の低い $\alpha$ 相の体積率が低鉄含有量の試料ほど多いことを示 唆している。さらに $\mathrm{T} 5 \mathrm{Fe}$ の $723 \mathrm{~K}-12 \mathrm{ks}$ 時効後のX線回折 結果を示したFig. 3 からも明らかなように， $\alpha$ 相の回折線 強度に比べて $\beta$ 相の回折線強度は非常に弱い。この現象は $\mathrm{T} 8 \mathrm{Fe}$ ，T10Feでも同様に認められ，723K-6 ks 時効から開 始される比抵抗，抵抗比の急減が完了した以降の時効時間 ではすべての試料で $\alpha$ 相の体積率が $\beta$ 相の体積率より多く
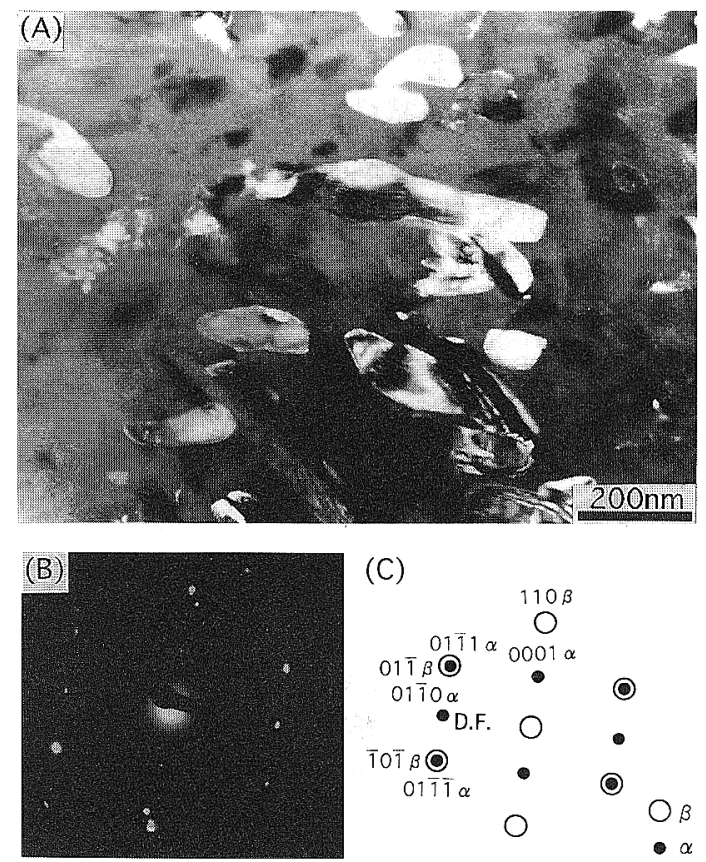

(C)

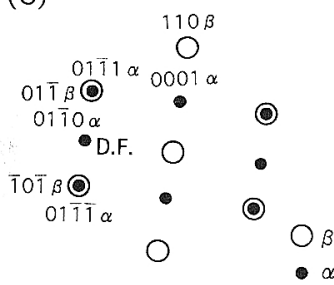

Fig. 11. TEM micrographs of $\mathrm{T} 10 \mathrm{Fe}$ aged at $723 \mathrm{~K}$ for $120 \mathrm{ks}$. A) Dark field image, B) SAD pattern, beam direction is [111] $\beta$ and C) Key diagram of SAD pattern in $B$ ).

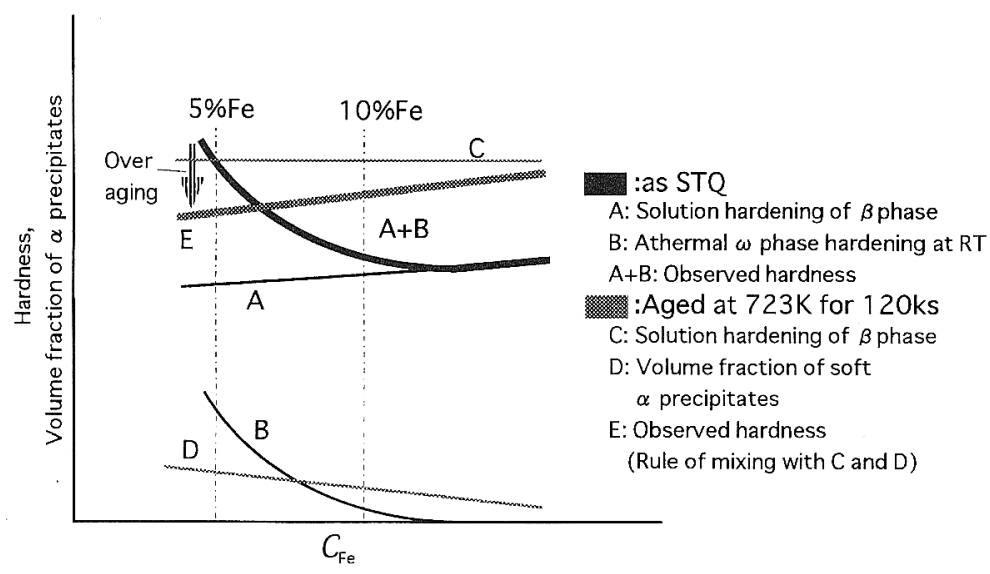

Fig. 12. Schematic representation of hardness change with Fe content, comparing the solution treated and quenched (STQ) state with the overaged condition. 
なっていると推定される。

アルミニウムや酸素などを添加していない本研究の試料 では $\mathrm{Ti}-\mathrm{Fe}$ 二元系状態図 ${ }^{19)}$ からも明らかなように， $\alpha$ 相に は $723 \mathrm{~K} て ゙ 100 \mathrm{ppm}$ 以下の鉄しか固溶せず，純チタンに近 い硬さを有していると考えられる。また，不純物として混 人した酸素が $\alpha$ 相に濃縮されて固溶している可能性もある が， $0.2 \%$ まで固溶してもその硬さは $200 \mathrm{HV}$ 以下であろう 201 このため $\alpha$ 相白体の強度はマトリックスである $\beta$ 相より低 いと推定される。

以上のように，析出相の大きさが時効 $\omega$ 相に比べて粗 大化している $723 \mathrm{~K}-120 \mathrm{ks}$ 時効後の試料では， $\alpha$ 相による 析出硬化量は極めて小さいと推定される。また，X線回折 からは析出 $\alpha$ 相の体積率がマトリックスである $\beta$ 相よりも 多くなっていると考えられ，硬さは $\alpha$ 相体積率変化による 複合則的硬化が支配的である。

すなわち，実際に観察される試料の硬さはFig.12に示す ように，鉄が濃縮して各試料同程度に硬化した $\beta$ 相と柔ら かい $\alpha$ 相に複合則を適用した Eのようになると考えられ る。高鉄含有量の試料では STQ 状態の硬さより硬化する が，T5FeのようにSTQ状態では室温で非熱的 $\omega$ 相が多量 に生成している試料の場合， $\beta$ 相への鉄の濃縮による硬 さ増加から $\alpha$ 相の析出による軟化を差し引いた硬化量よ $り も$ 非熱的 $\omega$ 相の消滅による軟化量の方が大き $<, \mathrm{Ti}-15 \mathrm{~V}-3 \mathrm{Cr}-3 \mathrm{Sn}-3 \mathrm{Al}^{8)}, \mathrm{Ti}-15 \mathrm{Mo}-5 \mathrm{Zr}^{9)}$, $\mathrm{Ti}-15 \mathrm{Mo}-5 \mathrm{Zr}-3 \mathrm{Al}^{10)}$ などでは認められない Ti-Fe 合金に特徵 的な過時効軟化が生じたのであろう。Fig. 7のSTQ状態と $0.3 \mathrm{ks}$ 時効状態では，鉄含有量の増加とともに硬さは低下 するが， $120 \mathrm{ks}$ 時効のように $\alpha$ 相が析出した状態では鉄含 有量の高い試料の方が硬さが高いことも上記の解釈で矛盾 なく説明できる。

\section{4. 結論}

$\mathrm{Ti}-5 ， 8 ， 10 \% \mathrm{Fe}$ 合金の $673 ， 723 ， 773 \mathrm{~K}$ 等温時効による比 抵抗と硬さ变化の追跡およびX線回折による析出相の同定 と TEMによる組織観察から以下のことが明らかになった。

1. $\mathrm{Ti}-5,8 \% \mathrm{Fe}$ 合金の等温時効による組織変化は $\beta \rightarrow$ $\omega+\beta \rightarrow \alpha+\beta \rightarrow \alpha+\mathrm{TiFe}$ である $\mathrm{Ti}-10 \% \mathrm{Fe}$ 合金では $723 \mathrm{~K} 以$ 下の時効温度では Ti-5，8\% Fe 合金と同様だが，773Kでは $\beta \rightarrow \alpha+\beta \rightarrow \alpha+\mathrm{TiFe}$ であり, 時効 $\omega$ 相の析出上限温度は
$723 \mathrm{~K}$ と773Kの間にあると考えられる。

2. $\alpha$ 相の析出開始は時効温度の上昇とともに早くなる。 $673 ， 723 \mathrm{~K}$ 時効では $\alpha$ 相析出開始は鉄含有量によってほと んど変わらない。773K 時効では明らかに鉄含有量が高い ほど遅くなる。

3. $723 \mathrm{~K}$ では $600 \mathrm{ks}$ から $\mathrm{TiFe}$ の析出に起因すると思われ る比抵抗，抵抗比および硬さの低下が認められる。

4. Ti-Fe 合金で認められる顕著な過時効軟化は，軟らか い $\alpha$ 相析出物の体積増加と焼入れ時には存在した非熱的 $\omega$ 相の消滅による軟化で定性的に説明できる。

\section{文献}

1) 例えば“Beta Titanium Alloys and Their Role in the Titanium Industry", Beta Titanium Alloys in the 1990's, ed. by D. Eylon, R. R. Boyer and D. A. Koss, TMS, Warrendale, (1993), 333.

2 ) 山川 良：チタン, 45 (1997), 105.

$3)$ 上龍洋明 : チタン, $45(1997), 133$.

4 ) チタンにおける低コスト化材料学の可能性を探る，日本鉄鋼 協会編，東京，(1997), 8 .

5 ）小松伸也, 池田勝彦, 杉本隆史, 龟井清, 井上幸一郎：日本 金属学会誌, 55 (1991), 491 .

6 ) 井上幸一郎, 池田勝彦, 小松伸也, 杉本隆史, 龟井清：鉄と 鋼, 84 (1998), 206.

7 ) 池田勝彦, 小松伸也，杉本隆史，龟井 清:軽金属，44 (1994), 35.

8 ) N.Niwa, T.Demura and K.Ito: ISIJ Int., 30 (1990), 773.

9 ) S.Komatsu, T.Sugimoto and K.Kamei: Titanium Science and Technology, ed. by H.Kimura and O.Izumi, Met. Soc. AIME, New York, (1980), 1353.

10) M.Ikeda, S.Komatsu, T.Sugimoto and M. Hasegawa: Mater. Sci. Eng., A243 (1998), 140.

11) 池田勝彦, 小松伸也, 杉本隆史, 亀井 清: 日本金属学会誌, 53 (1989), 664.

12）池田勝彦, 小松伸也, 杉本隆史, 龟井 清: 日本金属学会誌, 54 (1990), 743.

13）池田勝彦, 小松伸也, 杉本隆史, 龟井 清: 日本金属学会誌, 52 (1988), 144.

14）池田勝彦, 小松伸也, 杉本隆史, 龟井 清: 日本金属学会誌, 52 (1988), 1206.

15）竹元嘉利, 飛田守孝, 洣原 精：日本金属学会誌, 57 (1993), 261

16) B.S.Hickman: Trans. Met. Soc. AIME, 245 (1969), 1329.

17) G.W.Franti, J.C.Williams and H.I.Aaronson: Metall. Trans. A, 9A (1978), 1641.

18）大塩英世, 吉賀章政, 足立正雄：日本金属学会誌，33 (1969), 437

19) J.Matyka, F.Faudot and J.Bigot: Titanium science and technology, ed. by H.Kimura and O.Izumi, Met. Soc. AIME, New York, (1980), 2941.

20) Titanium; A Technical Guide, ed. by Matthew J.Donachie, Jr., ASM Int., Materials Park, (1988), 162. 